Universidade de Brasília

Centro de Excelência em Turismo

\title{
BOAS PRÁTICAS DE FABRICAÇÃO EM UMA UNIDADE DE ALIMENTAÇÃO DO DISTTRITO FEDERAL
}

Andrea Moya de Oliveira

Orientadora: Profa . Lucianne Cardoso 
UNIVERSIDADE DE BRASÍLIA

Centro de Excelência em Turismo

Curso de Especialização em Qualidade em Alimentos

\title{
BOAS PRÁTICAS DE FABRICAÇÃO EM UMA UNIDADE DE ALIMENTAÇÃO DO DISTRITO FEDERAL
}

\author{
Andrea Moya de Oliveira
}

Banca Examinadora

Lucianne Cardoso, mestre

Orientadora

Wilma Araújo, doutora

Membro da Banca

\begin{abstract}
Monografia apresentada ao Centro de Excelência em Turismo da Universidade de Brasília como requisito parcial para a obtenção do certificado de Especialista em Qualidade em Alimentos.
\end{abstract}


Oliveira, Andrea Moya

Boas Práticas de Fabricação em uma Unidade de Alimentação do Distrito Federal / Andrea Moya de Oliveira -- Brasília: UnB/CET, 2004.

vi, 72pág. :il.

Monografia (Especialização) - Universidade de Brasília, Centro de Excelência em Turismo, 2004.

Good Pratices of Production in one Unity of Alimentation in the District Federal.

1. Unidade de Alimentação e Nutrição. 2. Qualidade. 3. Boas Práticas de Fabricação - Monografia. 
Agradeço a Deus, pela sabedoria, pela força e graça que diariamente me proporcionou para a conclusão de mais esta etapa.

Aos meus pais, pelo amor, carinho e pela oportunidade que me deram de poder estar concluindo um curso de pósgraduação.

Às minhas irmãs pelo amor, carinho, companheirismo.

À professora e orientadora, Lucianne Cardoso, pela ajuda na realização deste trabalho. 
"Regras e padrões são instrumentos para liberar das mentes preguiçosas

o trabalho de pensar"

Levine 


\section{Resumo}

Nos últimos anos, o controle de qualidade passou a ser essencial nas indústrias alimentícias. Tornou-se fundamental a implantação de sistemas de gestão de qualidade para que as indústrias permanecessem no mercado. O cliente passou a exigir mais da qualidade dos produtos. Os empresários se viram obrigados a desenvolver suas indústrias, tornando-as mais competitiva e produtiva. Um dos principais atributos da qualidade de um alimento, ou refeição, é a sua condição higiênico-sanitária, que é o reflexo das características da matéria-prima e dos processos produtivos empregados. Atualmente, o controle sanitário de alimentos é fundamental para o sucesso de qualquer empresa do ramo alimentício. Desde a produção até o consumo, os alimentos passam por várias etapas, nas quais qualquer falha na higiene pode gerar contaminações, comprometendo a qualidade e acarretando sérias conseqüências às empresas responsáveis. Em função disto, há a necessidade de se implantar programas que estabeleçam normas de procedimento tais como as Boas Práticas de Fabricação.

Palavras-chaves: indústrias alimentícias, qualidade, Boas Práticas de Fabricação. 


\section{Summary}

In the last years, quality control started to be essential in the food industries. One became basic an implantation of systems of management of quality so that the industries remained in the market. The customer started to demand more of the product quality. The businessmen felt obliged to develop its industries, becoming them more competitive and productive. One of the main attributes of the quality of a food, or meal, is its hygienic- sanitary condition, that consequence of the characteristics of the raw material and the used productive processes. Currently, the sanitary control of food is basic for the success of any company of the branch foodstuff. From the production until consumption, the food pass for various stages, in which any imperfection in the hygiene can generate contaminations, compromising the quality and causing serious effects to the responsible companies. In function of this, there is a necessity to implant programs that establish procedure norms such as Good Practices of Production.

Keywords: food industries, quality, Good Practices of Production. 


\section{Su mário}

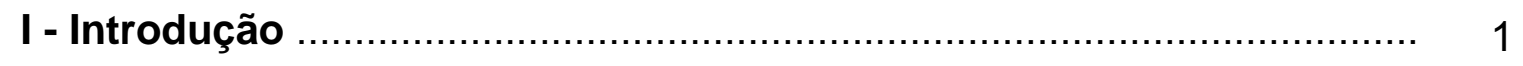

II - Revisão Bibliográfica ................................................................ 3

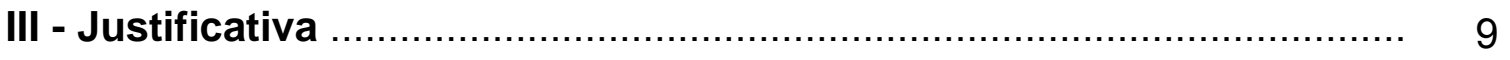

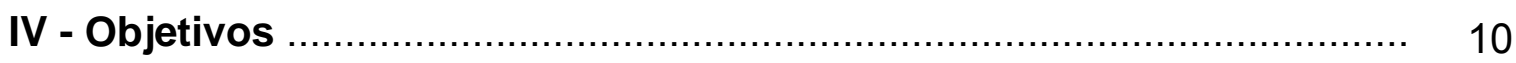

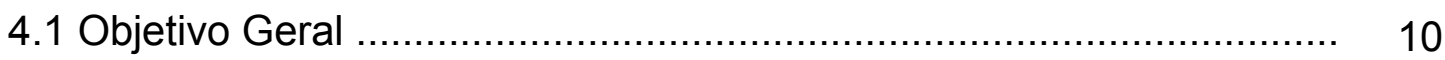

4.2 Objetivos Específicos ............................................................ 10

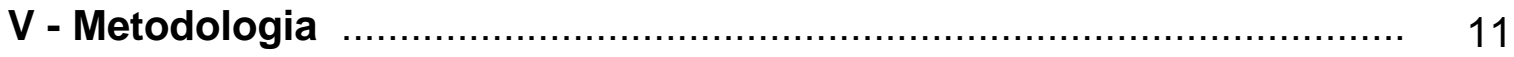

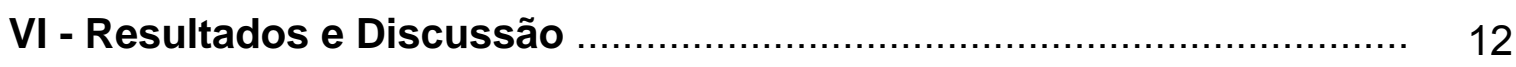

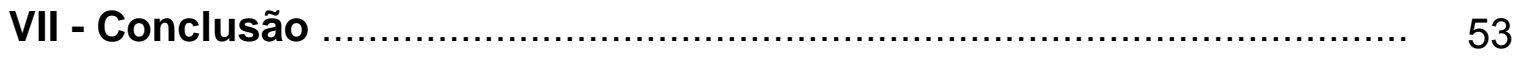

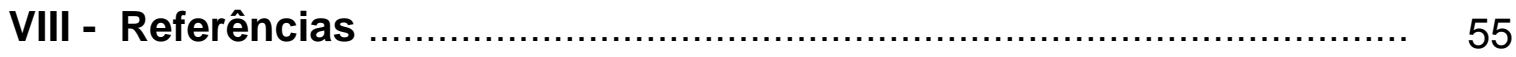

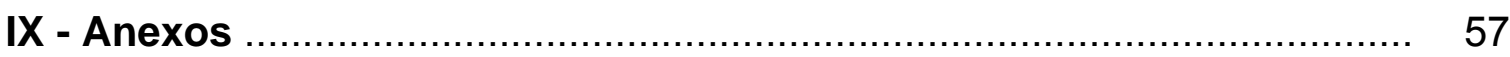




\section{Listade Abreviaturas e Siglas}

$\begin{array}{ll}\text { APPCC } & \text { - Análise de Perigos e Pontos Críticos de Controle } \\ \text { ASO } & \text { - Atestado de Saúde Ocupacional } \\ \text { BPF } & \text { - Boas Práticas de Fabricação } \\ \text { CIPA } & \text { - Comissão Interna de Prevenção de Acidentes } \\ \text { CIT } & \text { - Controle Integrado de Pragas } \\ \text { DHAA } & \text { - Direito Humano à Alimentação } \\ \text { EPI } & \text { - Equipamentos de Proteção Individual } \\ \text { OMS } & \text { - Organização Mundial de Saúde } \\ \text { PCC } & \text { - Pontos Críticos de Controle } \\ \text { PCMSO } & \text { - Programa de Controle Médico de Saúde Ocupacional } \\ \text { PNAN } & \text { - Política de Alimentação e Nutrição } \\ \text { POP } & \text { - Procedimentos Operacionais Padronizados } \\ \text { PPHO } & \text { - Procedimentos Padrões de Higiene Operacional } \\ \text { PVPS } & \text { - Primeiro que vence, primeiro que sai } \\ \text { SAN } & \text { - Segurança Alimentar e Nutricional } \\ \text { SBCTA } & \text { - Sociedade Brasileira de Ciência e Tecnologia de Alimentos } \\ \text { RT } & \text { - Responsável Técnico } \\ \text { UAN } & \text { - Unidade de Alimentação e Nutrição }\end{array}$




\section{I - Introdução}

Um dos atos mais importantes na vida do homem é a alimentação, não só pela necessidade de se nutrir, mas também pelas conotações sociais que tem este ato.

A caça, a pesca, a colheita de frutas e os pequenos cultivos eram as formas como as pessoas obtinham seus próprios alimentos. Caracterizavam-se por viver em pequenos grupos. Este século é marcado pelo grande crescimento populacional das cidades, provocando problemas referentes a consumo, transporte, armazenamento e distribuição de alimentos.

A legislação de alimentos teve início com as primeiras civilizações e abrangia a proibição do consumo de carnes de animais que não fossem mortos pelo abate. Os regulamentos antigos são descritos por FAO/OMS (1976) que relata o desenvolvimento do controle de alimentos através do início da história, na Idade Média e Resolução Industrial até os séculos IXX e XX.

Aliado ao desenvolvimento industrial e a falta de tempo das pessoas para 0 preparo de refeições, o consumo de alimentos industrializados passou a ser indispensável no dia-a-dia.

Durante muito tempo, se controlava a qualidade de alimentos, através de análises do produto final. Desta forma decorrem diversos problemas, pois devido a impossibilidade de inspecionar todos os produtos, pode ocorrer envio ao consumidor de produtos inadequados ou contaminados.

No setor alimentício, devido ao grande aumento da competitividade, em decorrência da nova postura do consumidor, da satisfação de suas necessidades, formou-se um padrão de qualidade de produtos e de serviços diferenciado das décadas anteriores.

A produção de refeições numa Unidade de Alimentação e Nutrição (UAN) tem como objetivo fornecer uma alimentação adequada às necessidades de sua clientela. As refeições oferecidas devem ser balanceadas, de modo a satisfazer as necessidades energéticas e em nutrientes, garantindo saúde, capacitação para o trabalho e condições físicas desejável ao indivíduo, além de seguras sob o aspecto de higiene. 
Tendo em vista uma produção alimentar segura e com qualidade, faz-se necessário a implantação das Boas Práticas de Fabricação (BPF), que envolve higiene pessoal, ambiental e de alimentos e todas as etapas que envolvem a manipulação de alimentos (recebimento, armazenamento, pré-preparo/preparação, coç̧ão, refrigeração, congelamento, reaquecimento e distribuição) (LIMA, 2001).

Sistemas de qualidade estabelecem a elaboração de manuais que definem ações para atingir metas estabelecidas. Os manuais obedecem a uma hierarquia e são elaborados a partir de um documento geral que determina a adoção de programas, de acordo com a natureza da empresa.

O Manual de Boas Práticas deve ser um descritivo real dos procedimentos técnicos para cada estabelecimento em especial, envolvendo os pré-requisitos básicos para uma perfeita produção dos alimentos (SILVA Jr, 2001).

O manual oferece ao profissional técnico responsável pela unidade um plano de controle higiênico-sanitário de refeições, com base na metodologia Análise de Perigos e Pontos Críticos de Controle (APPCC), que deve ser colocado em prática diariamente pelos funcionários da unidade, visando a qualificação de serviços prestados pela UAN através da padronização de normas e procedimentos, fundamentadas em critérios técnicos, na legislação específica e nas características da empresa e da clientela atendida. A execução dos padrões deve ser monitorada sistematicamente e as ações corretivas adotadas, quando necessário. As atividades de verificação garantem a manutenção da qualidade desejada, a fim de promover uma crescente melhoria nos padrões de atendimento a comensais.

O presente trabalho refere-se a implantação das BPF em uma Unidade de Alimentação e Nutrição, localizada no Distrito Federal. 


\section{II - Revisão Bibliográfica}

"A Alimentação e a Nutrição são direitos humanos fundamentais, consignados na Declaração Universal dos Direitos Humanos, e constituem requisitos básicos para a Promoção e a Proteção à Saúde, possibilitando a afirmação plena do potencial de Crescimento e Desenvolvimento Humano com Qualidade de Vida e Cidadania" (SAÚDE, 2003).

A Política Nacional de Alimentação e Nutrição (PNAN), homologada em 1999, integra a Política Nacional de Saúde, inserindo-se, ao mesmo tempo, no contexto da Segurança Alimentar e Nutricional (SAN) compondo o conjunto das políticas de governo voltadas para a concretização do direito humano universal à alimentação e nutrição adequadas (SAÚDE, 2003).

A PNAN visa orientar o Ministério da Saúde, órgão de planejamento, na elaboração de planos, programas, projetos e atividades na área da Alimentação e Nutrição. Dessa forma, a PNAN tem como propósito a garantia da qualidade dos alimentos colocados para o consumo no país, a promoção de práticas alimentares saudáveis e a prevenção e o controle dos distúrbios nutricionais, bem como o estímulo às ações intersetoriais que propiciem o acesso universal aos alimentos (SAÚDE, 2003).

Para o alcance do propósito da PNAN, são definidas como diretrizes:

- Estímulo às ações intersetoriais que propiciem o acesso Universal aos alimentos;

- Garantia da Segurança e da Qualidade dos produtos e da prestação de Serviços na Área de Alimentos;

- Monitoramento da Situação Alimentar e Nutricional;

- Promoção de Práticas Alimentares e Estilos de Vida Saudáveis;

- Prevenção e Controle dos Distúrbios Nutricionais e Doenças associadas à Alimentação e Nutrição;

- Promoção de Linhas de Investigação;

- Desenvolvimento e Capacitação de Recursos Humanos.

A PNAN tem como fundamentos a Segurança Alimentar e Nutricional (SAN) e o Direito Humano à Alimentação (DHAA). 
Na I Conferência Nacional de Segurança Alimentar em 1994, foi adotado o seguinte conceito de SAN "é a garantia, a todos, de condições de acesso à alimentos básicos de qualidade, em quantidade suficiente, de modo permanente e sem comprometer o acesso a outras necessidades básicas como saúde, educação, moradia, trabalho, lazer..., com base em práticas alimentares que contribuem assim, para uma existência digna em um contexto de desenvolvimento integral da pessoa humana." (SAÚDE, 2003)

A questão da segurança do alimento tem sido amplamente discutida, principalmente nos países desenvolvidos, pelos setores público e privado, assim como consumidores, visando disponibilizar pra a população alimentos que não sejam prejudiciais à saúde. Mesmo com grandes inovações tecnológicas nas várias fases das cadeias produtivas dos diferentes alimentos, tem sido notada a ocorrência de surtos de toxinfecção alimentar de forma crescente, o que é preocupante (RODRIGUES e SALAY, 2001).

As enfermidades transmitidas por alimentos são um dos maiores problemas que afetam a saúde da população da América Latina, sendo consideradas um importante problema de saúde pública. No final da década de 80, a OMS informou que mais de $60 \%$ das doenças de origem alimentar são toxinfecções alimentares, ou seja, os agentes etiológicos abrangem bactérias, vírus, fungos e parasitas, principalmente devido às práticas inadequadas de manipulação, matérias primas contaminadas, falta de higiene durante a preparação, além de equipamentos e estrutura operacional deficiente (SILVA Jr, 2001).

As fontes de contaminação, que são de interesse do ponto de vista sanitário, podem ser classificadas como primárias e secundárias. As fontes primárias são os reservatórios de germes patogênicos de origem alimentar, como, o homem, o esgoto, o solo, a água, o ar, os roedores, os insetos e os alimentos que chegam ao estabelecimento. As fontes secundárias incluem os equipamentos, os utensílios e a planta física (pisos, paredes, tetos e etc) (SILVA Jr, 2001).

O homem saudável é uma fonte potencial de alguns microrganismos, como: Staphylococcus aureus, Salmonella, Clostridium perfringens e Streptococcus faecalis (enterococos). Os estafilococos são habitantes comuns da pele, nariz, boca e garganta, e podem ser facilmente transferidos para o alimento. Entre os germes 
intestinais que são capazes de causar doenças de origem alimentar incluem-se salmonelas, Shigellas, Streptococcus faecalis, Clostridium perfringes e algumas cepas de Escherichia coli, que podem passar para os alimentos em virtude da higienização inadequada das mãos (SILVA Jr, 2001).

O controle de qualidade no Serviço de Alimentação é muito importante e abrangente, havendo a necessidade de se definir as situações básicas que envolvem a preparação dos alimentos, como as regras e técnicas adequadas para preparação em condições de segurança higiênico-sanitárias e as instruções de ensino teórico e prático para desenvolver as técnicas operacionais com manipulação e processamento seguro para não ocorrer toxinfecções alimentares (SILVA Jr, 2001).

A eficiência do controle da qualidade sanitária de um alimento, está fundamentada na capacidade de controle dos fatores, de origem física, química ou biológica, que contribuem para a contaminação, para a sobrevivência e para a multiplicação de microorganismos causadores de enfermidades transmitidas por alimentos (SILVA Jr, 2001).

Qualidade, conceito amplamente divulgado e almejado por vários setores da sociedade nos últimos anos, significa superioridade, excelência, representando para as empresas a satisfação de seus clientes, alcançada por meio da qualidade do atendimento, do serviço e, acima de tudo, do produto, que concentra em si a maior parte de sua imagem perante os consumidores. A qualidade é um sistema de melhoria contínua que precisa de mecanismos de controle efetivos que a garanta (VIALTA et al., 2002).

"Num mercado cada vez mais competitivo, preço e prazo ficam equiparados, o diferencial para o consumidor passa a ser então a qualidade dos produtos e serviços oferecidos, até porque esse consumidor está cada vez mais informado e consciente dos seus direitos" (LIMA, 2001).

Muito se discutiu nas duas últimas décadas sobre a mudança no enfoque da terminologia "qualidade". Sua importância passou a ser a garantia da qualidade de um produto ou serviço. 
O consumidor tornou-se o principal responsável por estas mudanças. É em função de seu comportamento, satisfação e necessidade que as indústrias direcionam o seu produto.

O setor de alimentos não pode ficar alheio a estas transformações, passando a buscar seu crescimento e manutenção através da melhoria da qualidade.

O aperfeiçoamento do controle de qualidade associa-se à percepção empresarial de que a atividade de controle na qualidade pode significar redução de perdas.

As mudanças somente são propostas ou pensadas quando se percebe que existem fatores que poderão colocar em risco o negócio da empresa ou quando passam por processos de contaminação em suas instalações e/ou produtos.

A necessidade de um sistema para controle de fabricação dos alimentos, para garantir a segurança dos consumidores, levou ao desenvolvimento de sistemas de controle de qualidade. A responsabilidade do controle de qualidade dos alimentos é dos indivíduos envolvidos em todas as etapas da cadeia alimentar, desde a fazenda até o consumidor final (SILVA Jr, 2001).

Para a implantação de um sistema de qualidade, é fundamental que o foco da empresa esteja sempre voltado ao cliente. O controle de qualidade é um sistema que objetiva assegurar ao produtor a fabricação de um alimento de excelente padrão e propiciar ao consumidor um produto em condições de cumprir sua finalidade de alimentar e nutrir, além de ser um produto seguro e que lhe traga satisfação (LIMA, 2001).

Visando melhorar as condições higiênico-sanitárias envolvendo a preparação de alimentos, o Ministério da Saúde publicou a Portaria $n^{\circ} 1428$ de 26/11/1993 (BRASIL, 1993) recomendando que seja elaborado um manual de boas práticas de manipulação de alimentos, baseado nas publicações técnicas da Sociedade Brasileira de Ciência e Tecnologia de Alimentos (SBCTA, 1994), Organização Mundial de Saúde (OMS, 1998) e Codex Alimentarius (WHO, 1993). Em agosto de 1997, foi publicada a Portaria Ministerial n 326 de 30/07/1997 (BRASIL, 1997), definindo melhor as condições técnicas para a elaboração do manual de boas práticas (SILVA Jr, 2001). 
Boas Práticas (BP) são normas de procedimentos para atingir um determinado padrão de identidade e qualidade de um produto e/ou um serviço na área de alimentação, cuja eficácia e efetividade deve ser avaliada através de inspeção e/ou investigação. As Boas Práticas (BP), no sentido de assegurar a qualidade higiênico-sanitária dos alimentos, deve consistir em procedimentos que permitam atingir os critérios de segurança, envolvendo a higiene (pessoal, ambiental e de alimentos) e manipulação (recebimento, armazenamento, prépreparo/preparação, cocção, refrigeração, congelamento, reaquecimento e distribuição) (SILVA Jr, 2001).

O Manual de BPF para indústria de alimentos (SBCTA, 1994) é a publicação que coloca o controle higiênico-sanitário das matérias-primas, como uma das prioridades para manipulação segura de alimentos (SILVA Jr, 2001).

O Manual de Boas Práticas é específico para cada estabelecimento e deve ser elaborado de acordo com a realidade desse. Além da identificação da empresa, responsabilidade técnica e demais dados que a caracterize, o manual segue os princípios descritos na Portaria $n^{\circ} 326$ - SVS/MS (BRASIL, 1997), como exemplificados:

a) Princípios gerais higiênico-sanitários das matérias para alimentos produzidos/industrializados;

b) Condições higiênico-sanitárias dos estabelecimentos produtores/ industrializadores de alimentos;

c) Requisitos de higiene dos estabelecimentos;

d) Higiene pessoal e requisito sanitário;

e) Requisitos de higiene de produção;

f) Controle de alimentos.

Os itens básicos para a elaboração do manual de BPF são: responsabilidade técnica, controle de saúde dos funcionários, controle da água para o consumo, controle das matérias-primas, controle integrado de pragas, visitantes, estrutura dos estabelecimentos, higiene, manipulação e transporte (SILVA Jr, 2001).

A atividade de controle, segundo FAYOL, consiste em verificar se tudo ocorre de conformidade com o plano adotado, as instituições emitidas e os princípios estabelecidos. Tem por objetivo apontar as falhas e os erros, para retificá-los e evitar 
a sua reincidência. Para um controle eficaz é imprescindível contar com um planejamento também eficaz, pois é nesta fase em que são estabelecidos padrões e parâmetros de avaliação que proporcionem uma visão clara e objetiva dos resultados a serem alcançados. Os padrões podem ser expressos em tempo, dinheiro, unidades físicas ou através de índices, e representam o desempenho desejado (TEXEIRA, 2000).

A adoção de BPF é um requisito fundamental em um Programa de Segurança Alimentar (PAS), aliado á implementação dos POP (Procedimentos Operacionais Padronizados), onde são documentados os procedimentos necessários para assegurar a ausência de perigos que possam comprometer a inocuidade dos alimentos. Estes são pré-requisitos para o Sistema de Análise de Perigos e Pontos Críticos de Controle (APPCC).

Conforme descrito na Resolução - RDC $n^{\circ} 275$ (BRASIL, 2002), Procedimento Operacional Padronizado (POP) é um procedimento escrito de forma objetiva que estabelece instruções seqüenciais para a realização de operações rotineiras e específicas na produção, armazenamento e transporte de alimentos.

Os POP's devem ser aprovados, datados e assinados pelo responsável técnico, responsável pela operação, responsável legal e ou proprietário do estabelecimento, firmando o compromisso de implementação, monitoramento, avaliação, registro e manutenção dos mesmos (BRASIL, 2002).

O Sistema APPCC é baseado numa série de etapas, inerentes ao processamento industrial dos alimentos, incluindo todas as operações que ocorre desde a obtenção da matéria-prima até o consumo do alimento, fundamentando-se na identificação dos perigos potenciais à segurança do alimento, bem como nas medidas para o controle das condições que geram perigos (SILVA Jr, 2001). 


\section{III - Justificativa}

A Portaria SVS/MS n 326 (BRASIL, 1997), em vigor desde de 30 de Julho de 1997, estabelece os requisitos gerais/essenciais de higiene e de boas práticas de fabricação, os quais devem ajustar-se todos os estabelecimentos produtores/industrializadores com a finalidade de obter alimentos aptos para 0 consumo humano.

Visando a adequação à ação da Secretaria de Vigilância Sanitária do Ministério da Saúde e, conseqüente, melhoria das condições higiênico-sanitárias envolvendo a preparação de alimentos desta UAN, faz-se necessário a implementação das Boas Práticas de Fabricação (BPF), envolvendo higiene pessoal, ambiental e de alimentos e, todas as etapas de manipulação de alimentos, a fim de garantir uma produção alimentar segura e com qualidade. 


\section{IV - Objetivos}

\subsection{Objetivo Geral}

- Implementar as Boas Práticas de Fabricação em uma Unidade de Alimentação e Nutrição.

\subsection{Objetivos Específicos}

- Identificar os perigos potenciais à segurança do alimento desde a obtenção de matérias-primas até o consumo do alimento;

- Estabelecer medidas de controle e monitorização dos perigos potenciais identificados;

- Elaborar o Manual de Boas Práticas de Fabricação a ser aplicado nesta Unidade de Alimentação e Nutrição, baseado nas características da unidade em estudo;

- Oferecer ao profissional técnico responsável pela unidade um plano de controle higiênico-sanitário de refeições, visando supervisão, coordenação e controle da implementação das normas de segurança alimentar;

- Qualificar os serviços prestados pela UAN através da padronização de normas e procedimentos, fundamentadas em critérios técnicos, na legislação específica e nas características da empresa e da clientela atendida;

- Garantir a obtenção de um alimento seguro e com qualidade para seus comensais. 


\section{V - Metodologia}

Este trabalho foi desenvolvido junto à diretoria da empresa, responsável técnica da unidade e todos os colaboradores, no período de janeiro de 2004 á março de 2004.

A Unidade de Alimentação e Nutrição (UAN) está localizada no Distrito Federal. Trata-se de uma empresa com fins lucrativos, prestadora de serviço de uma grande empresa multinacional.

A princípio foi realizado um diagnóstico da UAN para avaliar a adequação da mesma aos itens de legislação ou de padrões próprios. Para a realização do diagnóstico, utilizou-se uma lista de verificação, ou check-list, das Boas Práticas de Fabricação (BPF), conforme descrito na Portaria 275-M.S. O check-list, realizado pela RT da unidade, foi o instrumento de início da implantação da BPF, e por meio deste, foi possível verificar periodicamente o andamento e evolução do trabalho.

O check-list trata-se de um questionário em forma de tabelas contendo questões sobre os requisitos das BPF, levando a respostas de conforme (unidade atende aos requisitos), não conforme (unidade não atende ou atende parcialmente), não aplicável (requisito não se justifica em função do tipo de alimento elaborado pela unidade) e não observado (dependendo do ocorrido no local e no momento da verificação).

Com os resultados obtidos com o chek-list, foi montado um plano de ação visando a solução das não-conformidades (itens que não estão de acordo com a legislação). O plano de ação é um documento de orientação das ações que foram tomadas a partir de tal momento.

Posteriormente, baseado no plano de ação, elaborou-se Procedimentos Operacionais Padronizados (POP's) necessários, assim como as planilhas de controle.

Os POP's são documentos que descrevem detalhadamente os procedimentos operacionais da unidade.

Após a implantação das instruções, procedimentos e controles, elaborou-se o Manual de Boas Práticas de Fabricação, documento que contem todas as informações que comprovam a implantação das BP pela empresa. 


\section{$\mathrm{VI}$ - Resultados e Discussão}

Com atuação no segmento de refeições coletivas desde 1992, esta empresa administra, atualmente, cerca de 700 restaurantes corporativos distribuídos em 17 estados da Federação e no Distrito Federal, alcançando um número de 380.000 (trezentos e oitenta mil) refeições/dia.

Com o seu crescimento, foram necessários novos modelos de controle que garantissem a eficiência das operações. Portanto, a partir de 1997, algumas das unidades conquistaram pela primeira vez a Certificação ISO 9002.

A Unidade de Alimentação e Nutrição, referente ao presente trabalho, encontra-se localizada no Distrito Federal. Esta unidade foi inaugurada em dezembro de 2003, com objetivo de processamento com fins lucrativos, e está vinculada a uma grande empresa multinacional, fornecendo refeições para seus funcionários e/ou prestadores de serviço.

Esta unidade industrial segue as determinações do Programa de Alimentação do Trabalhador (PAT). Produz em média 500 (quinhentas) refeições/dia, que são servidas aos clientes no refeitório próprio da unidade. Não há o transporte de refeições.

A UAN possui infra-estrutura adequada para tal produção e oferece aos seus clientes as seguintes opções de refeições: café-da-manhã, almoço, lanche, jantar e ceia, além de atendimentos a diversos tipos de eventos, com funcionamento 24 horas diárias. É servido cardápio trivial simples, composto por preparações protéicas, guarnições, acompanhamentos e saladas.

Manual de Boas Práticas de Fabricação está descrito na Resolução - RDC $n^{\circ}$ 275 (BRASIL, 2002) como o documento que descreve as operações realizadas pelo estabelecimento, incluindo, no mínimo, os requisitos sanitários dos edifícios, a manutenção e higienização das instalações, dos equipamentos e dos utensílios, o controle da água de abastecimento, o controle integrado de vetores e pragas urbanas, controle da higiene e saúde dos manipuladores e o controle e garantia de qualidade do produto final. 


\section{1) Manual de Boas Práticas de Fabricação:}

\subsection{1) Recursos Humanos:}

\section{Organograma da unidade}

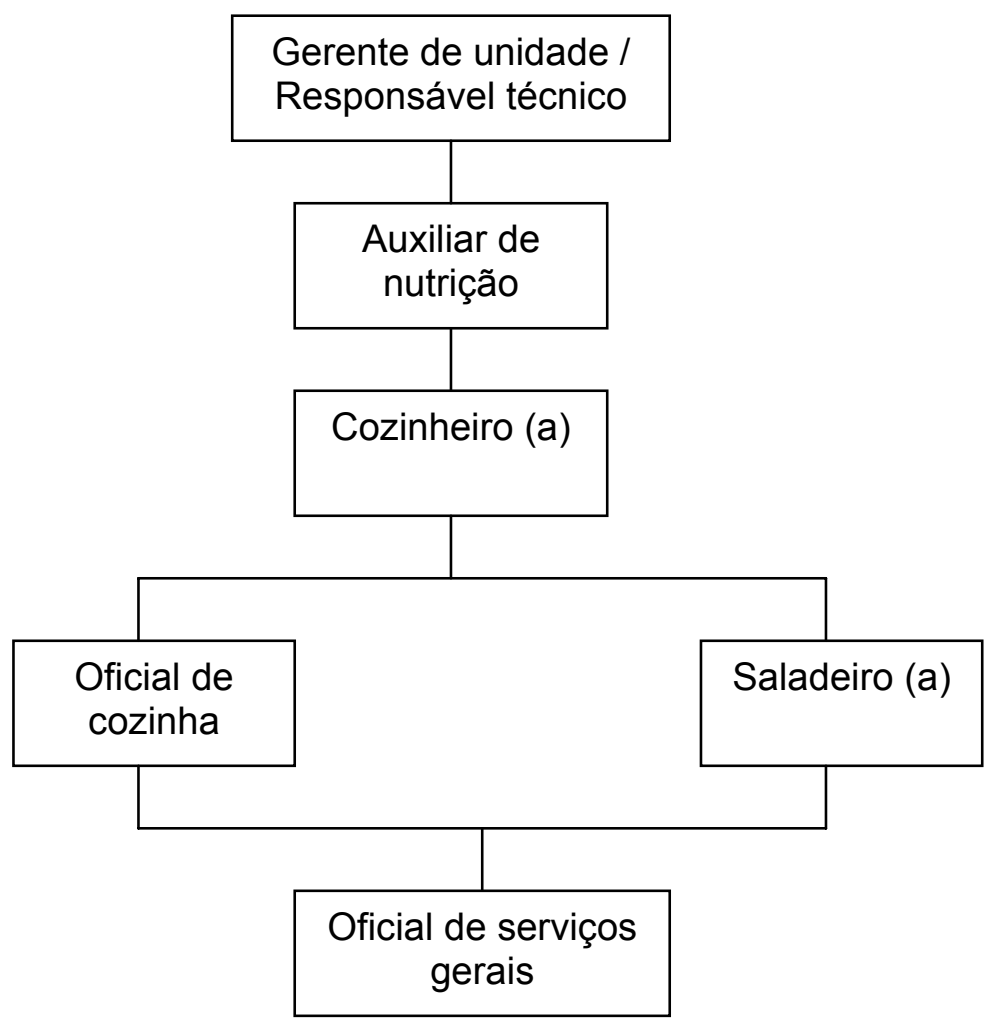

\section{Pessoal}

Quadro quantitativo de pessoal da unidade: 12 funcionários

- Gerente de unidade/responsável técnico: 01

- Auxiliar de nutrição: 01

- Cozinheiro (a): 02

- Oficial de cozinha: 02

- Saladeiro (a): 02

- Oficial de serviços gerais: 04

Total de funcionários por sexo:

- Feminino: 04

- Masculino: 08 
O quadro de pessoal desta unidade mostra-se compatível com o número de refeições produzidas e com as atividades desenvolvidas, contando com pessoal qualificado para a função exercida. Não há determinação de nível de escolaridade específico para contratação.

A contratação é regida de acordo com a CLT. Os funcionários cumprem carga horária de 44 horas semanais, com uma jornada de trabalho de 8 horas diárias, sendo 1 hora destinada ao almoço, e 1 folga semanal.

Durante o processo de produção de alimentos, se faz necessária a presença de profissionais habilitados, garantindo a qualidade e segurança dos mesmos, a fim de prevenir doenças veiculadas por alimentos e/ou a deterioração dos alimentos preparados.

O responsável técnico da unidade é um nutricionista, e este exerce a função de orientar e supervisionar todas as etapas da produção com auxílio de um auxiliar de nutrição.

\section{Recrutamento e Seleção}

Os funcionários são selecionados, através de análise de currículo e entrevista, e contratados pela gerente da UAN.

O processo de entrevista, teste específico (duração de quatro horas) e avaliação final do candidato é de responsabilidade da gerente da unidade (GU).

Os exames exigidos para admissão são: laboratorial (protoparasitológico) e clínico. Após a aprovação, o candidato será avaliado por um período de 90 dias de experiência.

Caso haja necessidade de substituição de funcionários e/ou aumento do número de funcionários, a gerente de unidade solicita novos colaboradores, mediante a aprovação da supervisão. É feito o preenchimento do formulário de requisição de pessoal, encaminhando-o para a agência após a aprovação para seleção dos novos colaboradores.

\section{Controle de Saúde}

Esse controle é um serviço terceirizado, sendo realizado por um profissional médico especializado em medicina do trabalho. 
São realizados os seguintes exames: exame médico admissional, periódico (anual), demissional, de retorno ao trabalho e de mudança de função.

É obrigatório a realização de exames médicos admissionais e periódicos acompanhados de análise laboratorial (protoparasitológico) e clínico, e outros, de acordo com avaliação médica.

Não é permitida a manipulação de alimentos por funcionários que apresentem feridas, lesões, chagas ou cortes nas mãos e braços, ou gastroenterocolites agudas ou crônicas, assim como aqueles que estiverem acometidos de faringites ou infecções pulmonares.

Todos os funcionários desta unidade encontram-se com Atestado de Saúde Ocupacional (ASO) atualizado, tendo em vista a recente contratação.

É realizada supervisão periódica do estado de saúde dos manipuladores e há registro dos exames realizados.

\section{Programa de Treinamento ou de capacitação dos manipuladores e supervisão \\ Existência de programa de capacitação adequado e contínuo relacionado à} higiene pessoal e à manipulação dos alimentos.

Treinamento realizado no próprio local, através de aulas expositivas e ilustradas por materiais didáticos (filmes educativos, slides, transparências...) que transferem conhecimentos básicos, nivelando os funcionários sobre as informações necessárias às boas práticas de manipulação, conservação e armazenamento de alimentos, assim como à estruturação da equipe.

Após o treinamento, os funcionários são sistematicamente orientados pela RT sobre as normas de higiene e procedimentos. Como método de avaliação, são realizadas observações diárias.

Existência de supervisão da higiene pessoal e manipulação dos alimentos.

Existência de supervisor comprovadamente capacitado.

Existência de registros dessas capacitações.

A periodicidade de treinamentos é semestral e/ou de acordo a identificação de necessidade. 
Foi realizado um treinamento dos atuais funcionários logo após a contratação dos mesmos. O treinamento foi elaborado e ministrado pela RT, e teve como conteúdo programático a higiene e manipulação de alimentos, envolvendo os procedimentos de boas práticas de manipulação adotados pela empresa (anexo 01).

$\mathrm{O}$ treinamento em higiene de alimentos e pessoal é um item de importância fundamental dentro dos recursos humanos. É necessário que exista um programa de treinamento e reciclagem para todos os funcionários. Treinamentos apropriados sobre higiene e manipulação higiênica de produtos alimentícios devem ser dados a todos os manipuladores, desde o início de seu contrato de trabalho. Devem ser realizadas avaliações periódicas da efetividade do treinamento. Os programas de treinamento devem ser revisados e atualizados rotineiramente, sempre que necessário. Portanto, faz-se necessário uma supervisão e orientações constantes, papel do profissional nutricionista dentro das UAN (SILVA Jr, 2001).

É necessário um monitoramento contínuo dos procedimentos e hábitos adotados pelos funcionários, desde sua chegada ao trabalho, durante a preparação de alimentos e após a cocção, sanificação ou qualquer outro processo de manipulação que envolva alimentos. O monitoramento, como forma de avaliação dos treinamentos e necessidade dos mesmos, deve sempre ser efetuado pela pessoa responsável pela cozinha, papel do profissional da nutrição. Os itens em desacordo deverão ser considerados para treinamentos periódicos, a fim de eliminar as dúvidas e evitar reincidência de problemas.

\section{Uniformes}

A gerente da unidade solicita ao departamento de uniformes.

Cada colaborador possui 02 (duas) trocas de uniformes, 01 (um) par de sapatos de segurança (couro) ou bota (PVC).

O uniforme é composto por: calça branca, camisa branca com golas vermelhas, avental de frente na cor branca, gorro branco e rede para cabelos.

Utilização de uniforme de trabalho de cor clara, adequado à atividade e exclusivo para área de produção.

Limpos e em adequado estado de conservação. 
Os aventais de PVC pertencem à unidade, e encontram-se disponíveis de acordo com as necessidades de cada área.

O modelo, o tipo e a cor dos uniformes são fatores que contribuem para amenizar o calor, comprometendo a produtividade e o padrão higiênico das refeições, pela possibilidade de favorecer a proliferação de bactérias e pela sudorese que acomete os funcionários. Por isso, os mais indicados são uniformes $100 \%$ de algodão e de cores claras.

Atualmente, todos os funcionários estão uniformes novos e completos, uma vez que os receberam na data de inauguração desta unidade (dezembro 2003). Todos os uniformes encontram-se em bom estado de conservação.

O uso de uniforme adequado é usual, pois a distribuição desses se deu atualmente e em número suficiente.

Deve-se lembrar que o nutricionista e o auxiliar (supervisores) devem dar o exemplo, não exigindo o uso de um acessório ou equipamento ou um certo comportamento ou ação se os mesmos não o fazem.

\section{Equipamentos de Proteção Individual - EPI's}

A gerente de unidade solicita ao técnico de segurança, através de uma comunicação interna, conforme as necessidades da unidade. Essas necessidades foram levantadas na primeira visita feita pelo técnico de segurança.

Os EPI's disponíveis atualmente nesta UAN são:

- Proteção frontal: aventais de PVC vermelho forrado;

- Proteção das mãos: 01 (uma) luva malha de aço, utilizada no prépreparo de carnes; 03 (três) luvas de borracha colorida, utilizada para higienização específica de cada área da unidade; 01 (um) par de luvas anti-térmicas.

- Proteção dos pés: botas PVC ou sapatos de segurança em couro.

Foi observado o uso adequado de EPl's na unidade.

\section{Hábitos higiênicos}

Todos os funcionários da empresa estão conscientes dos perigos que o consumidor pode sofrer por falta de higiene durante a manipulação. 
É realizada lavagem cuidadosa das mãos antes da manipulação de alimentos, principalmente após qualquer interrupção e depois do uso de sanitários.

Os manipuladores não espirram sobre os alimentos, não cospem, não tossem, não fumam, não manipulam dinheiro ou não praticam outros atos que possam contaminar o alimento.

Há cartazes de orientação aos manipuladores sobre a correta lavagem das mãos e demais hábitos de higiene, afixados em locais apropriados.

A higiene e conduta pessoal dos manipuladores são fatores de extrema importância de controle como garantia da qualidade de alimentos, tendo em vista que o homem é um dos principais portadores de microrganismos e parasitas.

É necessário proporcionar todas as facilidades para que se obtenha um alto padrão de higiene pessoal.

\subsection{2) Edificações e Instalações:}

\section{Localização da unidade e arredores}

O estabelecimento é localizado no térreo, em setor destinado a indústrias de alimentos. O espaço físico é adequado às necessidades de produção. Situa-se em zona isenta de odores indesejáveis, fumaça, pó e outros contaminantes e não encontra-se exposto a inundações.

Área pavimentada, livre de focos de insalubridade, ausência de lixo, objetos em desuso, animais, insetos e roedores.

\section{Área externa}

A área externa com iluminação, livre de focos de insalubridade, de objetos em desuso ou estranhos ao ambiente, de vetores e outros animais no pátio e vizinhança; de focos de poeira; de acúmulo de lixo nas imediações, de água estagnada, dentre outros. Existência de calçadas contornando as instalações.

\section{Área interna}

Área interna livre de objetos em desuso ou estranhos ao ambiente. 


\section{Acesso}

O acesso é direto, não comum a outros usos.

As vias e áreas utilizadas para circulação, que se encontram dentro de seu perímetro de ação, têm uma superfície dura, pavimentada, portanto adequada para o trânsito sobre rodas. Dispõe de um escoamento adequado, assim como controle de meios de limpeza.

As vias de acesso interno com superfície pavimentada são adequadas ao trânsito sobre rodas, com escoamento adequado e sempre limpas.

\section{Piso}

Nas áreas de manipulação de alimentos, o piso observado é do tipo gail, que caracteriza-se por ser um material liso, resistente ao trânsito, impermeável, lavável, antiderrapante, de fácil higienização e manutenção. Coloração clara com rejunte da mesma cor (bege). Pelo fato de não ser monolítico (sem rejunte) há um aumento de dificuldade para higienização e visualização da sujeira.

Encontra-se em adequado estado de conservação (livre de defeitos, rachaduras, trincas, buracos e outros).

O piso é em um único nível, não havendo o risco de acidente de trabalho. Não há inclinação do piso em direção ao ralo, o que dificulta o escoamento da água. Ralos sifonados e grelhas removíveis são colocados em número e locais adequados de forma a facilitar o escoamento e proteger contra a entrada de baratas, roedores etc. Encontram-se localizados nas entradas da despensa, área de salada, higienização e coç̧ão.

\section{Tetos}

Acabamento liso, em cor clara (branco), impermeável, de fácil limpeza e desinfecção. Encontra-se em adequado estado de conservação. Não há goteiras, vazamentos, umidade, trinca, rachadura, bolor e descascamento. 


\section{Paredes e divisórias}

Material liso, resistente, impermeável e lavável, em cor clara, sendo revestidas de azulejos brancos com rejunte brancos. Em adequado estado de conservação (livres de falhas, rachaduras, umidade, descascamento e outros).

Apesar do material isoladamente ser higiênico, há uma grande dificuldade de limpar adequadamente as junções. Nas paredes não existem cantoneiras e barras de aço, não sendo necessário por não haver circulação de carros.

Não observa-se a existência de ângulos abaulados herméticos entre as paredes e o piso e entre as paredes e o teto.

\section{Portas}

Portas de madeira revestida com material lavável, com superfície lisa, de fácil higienização, sem falhas de revestimento. Portas externas possuem fechamento automático (mola), telas milimétricas e borracha de vedação na extremidade inferior das portas, como formas de proteção eficazes para impedir o acesso e abrigo de pragas.

\section{Janelas e outras aberturas}

Com superfície lisa (vidros lisos e transparentes), de fácil higienização, ajustadas aos batentes, em adequado estado de conservação (livres de falhas, rachaduras, umidade, descascamento e outros). Existência de proteção anti-pragas através de telas milimétricas fixas, o que dificulta uma higienização adequada.

Localizadas na parte superior das paredes, objetivando o conforto térmico, evitar a incidência dos raios solares diretamente sobre a superfície de trabalho, não constituindo-se fontes de contaminação. Todas as janelas têm comunicação direta com o exterior.

Não observa-se ângulo de $30^{\circ}$ no parapeito externo das janelas, facilitando o acúmulo de sujeiras.

\section{Escadas, elevadores de serviço, montacargas e estruturas auxiliares}

Não é observado a existência destes nesta UAN. 


\section{Instalações sanitárias e vestiários para os manipuladores}

Localizados isolados da área de produção, através de barreira física, não havendo comunicação direta com a área de trabalho e de refeições. Independentes para cada sexo (conforme legislação específica), são identificados e de uso exclusivo para os manipuladores de alimentos.

Portas com fechamento automático (mola). Pisos e paredes (vide itens respectivos) são adequados e apresentam satisfatório estado de conservação. Provenientes de iluminação natural e artificial. A ventilação é conseguida por meio de janelas teladas, localizadas na parte superior das paredes, com comunicação direta com o exterior.

Apresentam-se organizados e em adequado estado de conservação.

Instalações sanitárias com: vasos sanitários; mictórios (banheiro masculino); lavatórios em proporção adequada ao número de empregados (conforme legislação específica); chuveiros em número suficiente (conforme legislação específica), com água fria; lixeiras sem tampas, com coleta freqüente do lixo; armários individuais para todos os manipuladores, onde ficam armazenados todos os pertences dos funcionários; produtos destinados à higiene pessoal: papel higiênico, sabonete líquido inodoro anti-séptico e toalhas de papel não reciclado para as mãos; água corrente, dotadas de torneira com fechamento automático e conectadas à rede de esgoto; avisos sobre a obrigatoriedade e a forma correta de lavagem das mãos, após o uso do sanitário.

As instalações sanitárias são importantes no processo de higiene em toda a cadeia produtiva uma vez que se não forem bem instaladas e não tiverem os requisitos necessários para uma boa higiene dos funcionários, poderão contribuir de forma direta ou indireta para contaminar as áreas de produção.

As orientações referentes a vestuário, banheiros e sanitários são as constantes da norma regulamentadora $n^{\circ} 24$, da Portaria $n^{\circ} 3214$, do Ministério do Trabalho que especifica que deve-se ter: um sanitário para cada 20 funcionários, com separação por sexo; lavatório com sabão e toalha, de preferência descartável; papel higiênico e cesto com tampa; um chuveiro para cada 10 funcionários, com separação por sexo; vestiário dotado de armários individuais, observada a separação por sexo e a área física de 1,5 metro quadrado por cada funcionário. Nos 
lavatórios devem ter uma advertência lembrando a higienização das mãos após o uso dos mesmos. Estes ambientes devem estar sempre limpos e ventilados, devendo a higienização ser feita quantas vezes forem necessário.

\section{Lavatórios na área de produção}

Para entrar/retornar para a área de manipulação de alimentos, observa-se a existência de apenas 01 lavatório com água corrente, torneira sem acionamento automático, localizado em ponto estratégico, na entrada da área. O número é suficiente de modo a atender toda a área de produção. Lavatório dotado de sabonete líquido inodoro anti-séptico, toalhas de papel não reciclado.

\section{Instalações sanitárias para visitantes e outros}

Encontram-se instaladas totalmente independentes da área de produção.

\section{lluminação e instalação elétrica}

A iluminação artificial é adequada, permitindo que as atividades de produção sejam eficientemente desenvolvidas. As lâmpadas são fixas, provenientes de luz branca, fluorescente. Todas as luminárias encontram-se com proteção de acrílico adequada contra quebras e em bom estado de conservação. As lâmpadas são distribuídas uniformemente pelo ambiente, sem ofuscamento, reflexos fortes, sombras e contrastes excessivos. A intensidade de iluminação é 220 lux nas áreas de trabalho. Não há incidência de luz solar na cozinha, o que prejudica a ambiência.

A iluminação exerce uma forte influência no comportamento das pessoas. Sua utilização adequada evita doenças visuais, aumenta a eficiência do trabalho e diminui o número de acidentes. A iluminação mais recomendada para as UAN é a natural, apesar de não dispensar a instalação de rede elétrica. Lâmpadas fluorescentes também são adequadas por ser a iluminação branca, por manter a cor natural dos alimentos, e não contribuir para a elevação da temperatura no local. As lâmpadas devem possuir sistema de segurança e proteção, evitando quedas acidentais que oferecem risco aos alimentos e aos funcionários. Quanto mais inadequada a iluminação do ambiente, conseqüentemente menor a eficiência do trabalho e maior o risco de acidentes (TEIXEIRA, 2000). 
As instalações elétricas são embutidas. Não é observada fiação elétrica solta sobre a zona de manipulação de alimento.

\section{Ventilação e climatização}

A ventilação é garantida pela distribuição de janelas teladas na cozinha e presença de duas portas teladas, tipo vai-vem, uma com acesso direto à área de recepção de mercadorias, e a outra com acesso direto ao refeitório. O refeitório é climatizado, com ar condicionado. Não há dificuldade no controle de pragas. A temperatura do ambiente gira em torno de 30 graus, o que não é compatível com as operações realizadas num serviço de alimentação, tendo em vista que a coifa ainda não teve sua completa instalação, comprometendo a eliminação do ar contaminado.

Uma temperatura de $22^{\circ}$ a $26^{\circ} \mathrm{C}$, com umidade relativa de 50 a $60 \%$ é considerada compatível com as operações realizadas numa U.A.N. O conforto térmico pode ser assegurado por meios que permitam a circulação natural do ar. Quando não for possível, o mais indicado é recorrer a meios artificiais, como, ventiladores, circuladores, exaustores que, além de retirar o ar quente, amenizam a presença de odores (TEIXEIRA, 2000).

A inadequação da ventilação gera desconforto térmico, prejudicando a realização de qualquer tipo de trabalho. Temperaturas muito altas causam mal estar, diminuindo a produção, além do que o suor é uma possível fonte de contaminação. Em cozinhas, é importante à renovação do ar devido à exalação constante de vapores provenientes dos processos de cocção.

Um aspecto muito importante que tem influência direta sobre o conforto térmico é o uniforme dos funcionários, que pode comprometer a produtividade e o padrão higiênico das refeições.

\section{Controle integrado de vetores e pragas urbanas}

A responsabilidade pela execução do Controle de Pragas é do cliente (contratante) e está estabelecida no Contrato de Prestação de Serviços.

Independentemente da responsabilidade conforme acima definida, cabe ao gerente da UAN manter um adequado acompanhamento sobre a realização dos controles de pragas e disponibilizar a unidade para tal serviço nas datas estipuladas. 
O controle de pragas e roedores é realizado com periodicidade mínima de 6 meses.

No caso de necessidade de adoção de controle químico, os produtos usados na desinsetização e desratização obedecem às especificações do fabricante para utilização em depósitos de alimentos e são aprovados pela legislação vigente (Portaria SNVS n 10 de 8/3/85). Nesse caso, há a existência de comprovante de execução do serviço expedido por empresa especializada.

O responsável técnico é informado sobre os produtos utilizados, as respectivas concentrações e a periodicidade de aplicação e período de ocorrência.

Os gêneros, durante a desinsetização, permanecem cobertos com plásticos para evitar que sejam contaminados pelos venenos pulverizados.

Não é observada a presença de vetores e pragas urbanas ou qualquer evidência de sua presença como fezes, ninhos e outros.

São adotadas medidas preventivas e corretivas com o objetivo de impedir a atração, o abrigo, o acesso e ou proliferação de vetores e pragas urbanas que comprometam a segurança do alimento. Tais medidas mostram-se bastante eficazes por não ter havido infestações até o momento.

O Controle Integrado de Pragas (CIT) no Serviço de Alimentação é indispensável na prevenção de toxinfecções alimentares. Tem sua importância na transmissão de microrganismos patogênicos, pois são detectados importantes grupos de microorganismos nas próprias pragas e em seus resíduos. Deve-se considerar também os sentimentos de repulsa que a presença destes animais causa, gerando reclamações por parte dos clientes, chegando a comprometer a idoneidade do estabelecimento e de seus responsáveis. Geralmente, a presença de pragas é associada à falta de higiene, mas muitas vezes a presença destes animais está relacionada com o desconhecimento de medidas preventivas e corretivas do ambiente, falta de treinamento, além de um planejamento estrutural deficiente (SILVA Jr, 2001).

\section{Abastecimento de água}

O abastecimento é ligado à rede pública, com sistema de captação própria, protegido, revestido e distante de fonte de contaminação. 
Observa-se a existência de reservatório de água acessível com instalação hidráulica com volume, pressão e temperatura adequados, dotado de tampas, em satisfatória condição de uso, livre de vazamentos, infiltrações e descascamentos.

Há a existência de responsável comprovadamente capacitado para a higienização do reservatório da água, que é feita com apropriada freqüência, por uma empresa terceirizada com registros e comprovantes da execução do serviço.

Os encanamentos em estado satisfatório e ausência de infiltrações e interconexões, evitando conexão cruzada entre água potável e não potável.

Obrigatoriamente há uma planilha de registro da troca periódica do elemento filtrante.

Com relação à potabilidade da água, esta é atestada por meio de laudos laboratoriais, com adequada periodicidade, expedidos por empresa terceirizada, assinados por técnico responsável comprovadamente capacitado.

A qualidade da água é muito importante, devido a sua participação nas várias etapas da produção de alimentos e da higienização de ambiente, manipuladores, equipamentos e utensílios.

\section{Esgotamento sanitário}

Fossas, esgoto conectado à rede pública, caixas de gordura em adequado estado de conservação e funcionamento.

\section{Manejo dos resíduos}

A coleta de resíduos no interior do estabelecimento é feita em recipientes de aço inox com acionamento por pedal, de fácil higienização e transporte, devidamente identificados e higienizados constantemente. Uso de sacos de lixo apropriados, com retirada freqüente dos resíduos da área de processamento, evitando focos de contaminação.

A estocagem dos resíduos na área externa é realizada em containeres do governo. Lixo e resíduos armazenados externamente, fora das áreas de manipulação em área adequada para a sua estocagem. 


\section{Lay-out}

Lay-out é adequado ao processo produtivo em número, capacidade e distribuição das dependências de acordo com a atividade de produção. O espaço foi construído de forma adequada, especificamente para este serviço, sendo o projeto e todos os equipamentos novos.

O lay-out desta UAN foi realizado por uma equipe multiprofissional da empresa contratante, contando com a participação de um profissional nutricionista da empresa contratada, com experiência em implantar restaurantes, o que possibilitou o planejamento físico desta unidade de alimentação com padrões e requisitos específicos, com conseqüente redução de problemas de natureza técnica operacional, de prejuízos e de insatisfação dos usuários.

No lay-out ficam estabelecidos as posições dos setores, os acessos à circulação, os fluxos, a localização e as instalações dos equipamentos.

Nesta UAN, as áreas para recepção e depósito de matéria-prima, ingredientes e embalagens são distintas das áreas de produção, armazenamento e expedição de produto final.

A cozinha está dividida fisicamente em 12 (doze) compartimentos:

- Recepção de mercadorias;

- Sanitários feminino e masculino;

- Estoque de materiais de limpeza;

- Estoque de gêneros não perecíveis;

- Área de saladas;

- Área de sobremesa e café;

- Área de pré-preparo de carnes;

- Área de cocção;

- Higienização de panelas e utensílios;

- Higienização de pratos e talheres;

- Sala da nutricionista;

- Refeitório.

Durante o planejamento físico de uma UAN, deve ser levado em conta a existência de espaços suficientes para atender de maneira adequada, a toda as operações. $O$ desenho deve ser tal que permita uma limpeza adequada e permita a 
devida inspeção quanto a garantia da qualidade higiênico -sanitária do alimento. Os edifícios e instalações devem impedir a entrada e o alojamento de insetos, roedores e ou pragas e também a entrada de contaminantes do meio, tais como: fumaça, pó, vapor, e outros. Os edifícios e instalações devem ser projetados de forma a permitir a separação, por áreas, setores e outros meios eficazes, como definição de um fluxo de pessoas e alimentos, de forma a evitar as operações suscetíveis de causar contaminação cruzada. Os edifícios e instalações devem ser projetados de maneira que seu fluxo de operações possa ser realizado nas condições higiênicas, desde a chegada da matéria-prima, durante o processo de produção, até a obtenção do produto final (BRASIL,1997).

\subsection{3) Equipamentos, móveis e utensílios:}

\section{Equipamentos}

Os equipamentos da linha de produção desta UAN têm desenho e número adequado à atividade, e estão dispostos de forma a permitir fácil acesso e higienização adequada. A localização destes atende ao fluxo racional das operações, evitando cruzamento e retornos desnecessários, de modo a evitar poluição sonora.

Todos os equipamento e utensílios, utilizados nos locais de manipulação de alimentos, são confeccionados de materiais como inox, pvc, e plásticos, por não transmitirem substâncias tóxicas, odores e sabores, por serem não absorventes, resistentes à corrosão e são capazes de resistir a repetidas operações de limpeza e desinfecção. As superfícies em contato com alimentos são lisas, íntegras, impermeáveis, resistentes à corrosão, de fácil higienização e de material não contaminante. Todos os equipamentos encontram-se em adequado estado de conservação e funcionamento.

É proibido o uso de madeira e de outros materiais que não possam ser limpos e desinfetados adequadamente. Tendo em vista que peças de madeiras possuem reentrâncias microscópicas que acumulam sujidades e restos de alimentos atraindo roedores e servindo de abrigo para insetos, portanto devem ser eliminados das atividades das seções. 
Equipamentos de conservação dos alimentos (refrigeradores, congeladores, câmaras frigoríficas e outros), bem como os destinados ao processamento térmico, têm medidor de temperatura localizado em local apropriado e encontram-se em adequado funcionamento.

Observa-se nesta UAN a presença de:

- 02 (dois) freezeres horizontais, localizado no estoque de mercadorias, destinado ao armazenamento de carnes e aves;

- 01 (um) refrigerador vertical com 08 portas, localizado no estoque de mercadorias, destinado ao armazenamento de frios, leite e derivados, ovos, sobremesas;

- 01 (um) refrigerador com 04 (quatro) portas, localizado na área de saladas, destinado ao armazenamento de produtos de FLV;

- 01 (um) descascador de legumes, localizado na área de saladas;

- 01 (um) multi-processador de legumes, localizado na área de saladas;

- 01 (uma) batedeira industrial, localizada na área de sobremesas;

- 01 (uma) cafeteira industrial, localizada na área de sobremesas e café;

- 01 (um) moedor de carnes, localizado na área de pré-preparo de carnes;

- 01 (um) forno combinado localizado na área de cocção;

- 01 (um) caldeirão 50 (cinqüenta) litros localizado na área de cocção;

- 01 (um) fogão industrial 10 (dez) bocas localizado na área de cocção;

- 01 (uma) máquina industrial de lavar pratos e bandejas localizado na área de higienização;

- 01 (um) triturador de resíduos localizado na área de higienização;

- 01 (um) pass-trough localizado na área de cocção/refeitório;

- 01 (um) balcão quente com 06 (seis) lugares localizado no refeitório;

- 01 (um) balcão frio com 07 (sete) lugares localizado no refeitório.

Verifica-se a existência de planilhas de registro da temperatura, conservadas durante período adequado (anexo 02). 
Existência de registros que comprovam a calibração dos instrumentos e equipamentos de medição e comprovante da execução do serviço realizado pela empresa terceirizada contratada pelo cliente.

Os equipamentos complementam o planejamento da área física, uma vez que sua localização define o lay-out da área das UAN.

O dimensionamento dos equipamentos tem estreita relação com o número de refeições, política de compras, tipo de cardápio, quadro de pessoal, disponibilidade econômica da instituição, sistema de distribuição e tipo de combustível a ser utilizado na UAN.

Conforme descrito na Portaria $n^{\circ} 326$ (BRASIL, 1997), todos os equipamentos e utensílios devem ser desenhados e construídos de modo a assegurar a higiene e permitir uma fácil e completa limpeza e desinfecção e, quando possível, devem ser instalados de modo a permitir um acesso fácil e uma limpeza adequada, além disto devem ser utilizados exclusivamente para os fins a que foram projetados.

\section{Móveis (mesas, bancadas, vitrines, estantes)}

Em número suficiente, de material apropriado, resistentes, impermeáveis; em adequado estado de conservação, com superfícies íntegras.

Com desenho que permita uma fácil higienização (lisos, sem rugosidades e frestas).

\section{Utensílios}

Todos os utensílios (talheres, taças, bandejas) são de aço inox, que caracteriza-se por ser um material não contaminante, resistente à corrosão, de tamanho e forma que permitam fácil higienização. Encontram-se em adequado estado de conservação e em número suficiente e apropriado ao tipo de operação utilizada.

São armazenados em um armário, fechado, de aço inox, de forma organizada e protegidos contra a contaminação, conforme solicitação da inspeção de saúde. $\mathrm{O}$ armário localiza-se na entrada da área de higienização, não sendo necessário atravessar toda a área para pegar um utensílio limpo, o que não é adequado visto 
que pode ocorrer contaminação cruzada, dos utensílios já higienizados com os utensílios sujos.

\subsection{4) Requisitos de Higiene do estabelecimento:}

Existência de um responsável pela operação de higienização comprovadamente capacitado, no caso o funcionário responsável pela área. Com a uma freqüência de higienização adequada e registrada.

Os produtos para a higienização são regularizados pelo Ministério da Saúde, estar disponíveis, identificados e guardados em local adequado. A diluição, o tempo de contato e o modo de uso/aplicação obedecem às instruções recomendadas pelo fabricante.

Disponibilidade e adequação dos utensílios (escovas, esponjas etc.) necessários à realização da operação. Em bom estado de conservação.

O cloro é o agente químico mais utilizado para efetuar higienização de áreas de preparo de alimentos por apresentar pode bactericida e fungicida, e ser de baixa toxicidade em concentrações recomendadas.

\subsection{5) Etapas do processo:}

\section{Matéria-prima, ingredientes e embalagens}

As operações de recepção da matéria-prima, ingredientes e embalagens são realizadas em local protegido e isolado da área de processamento, por barreira física, sendo estas inspecionadas na recepção. Não é observada a existência de planilhas de controle na recepção (temperatura e características sensoriais, condições de transporte e outros).

Matérias-primas, ingredientes e embalagens reprovados no controle efetuado na recepção são devolvidos imediatamente para o fornecedor e/ou identificados e armazenados em local separado.

Vale enfatizar que todos os rótulos das matérias-primas atendem à legislação, e a seleção destes produtos é realizada pela equipe de suprimentos, formada por profissionais capacitados para a atividade, e é feita baseada em critérios relacionados à segurança dos alimentos. 
Armazenamento em local adequado e organizado, sobre paletes, conservados e limpos e/ou sobre prateleiras de aço afastadas das paredes e distantes do teto de forma que permita apropriada higienização, iluminação e circulação de ar. Uso das matérias-primas, ingredientes e embalagens respeita a ordem de entrada dos mesmos, sendo observado o prazo de validade, sendo utilizado o sistema PVPS (primeiro que vence, primeiro que sai).

Acondicionamento adequado das embalagens a serem utilizadas.

A rede de frio existente é adequada ao volume e aos diferentes tipos de matérias-primas e ingredientes, sendo estes armazenados de acordo com sua origem.

\section{Fluxo de produção}

Locais para pré - preparo ("área suja") são isolados da área de preparo por barreira física e/ou técnica. Os funcionários são capacitados para obediência do fluxo adequado estipulado pelo responsável técnico.

O fluxo é ordenado, linear e sem cruzamento.

Há controle da circulação e acesso restrito para visitantes.

\section{Controle de qualidade do produto final}

Há a existência de programa de amostragem para análise laboratorial do produto final. Diariamente, em cada refeição, são coletadas amostras de todas as preparações ( $100 \mathrm{~g}$ de cada preparação). A coleta é realizada durante a distribuição, $1 / 3$ do tempo antes do término da distribuição. As amostras são coletas para eventuais análises microbiológicas no caso de ocorrência de surtos alimentares e/ou por solicitação do cliente. As análises microbiológicas, químicas e físicas são feitas por laboratório terceirizado que também possua um padrão de qualidade atestado. As sensoriais são realizadas na própria empresa.

Quando as análises são realizadas, verifica-se a existência de laudo laboratorial atestando o controle de qualidade do produto final, expedido por empresa terceirizada.

Não é observada a existência de equipamentos e materiais necessários para análise do produto final realizadas no estabelecimento. 


\section{Transporte do produto final}

Não há transporte de refeições.

\section{2) Procedimentos Operacionais Padronizados - POP's:}

Os POP's contribuem para a garantia das condições higiênico-sanitárias necessárias ao processamento/ industrialização de alimentos, complementando as Boas Práticas de Fabricação.

Neste trabalho, os POP's foram desenvolvidos como referenciais teóricos para serem, posteriormente, documentados e implementados na unidade.

Os POP's podem ser apresentados como anexo do Manual de Boas Práticas de Fabricação do estabelecimento (BRASIL, 2002).

Conforme descrito na Resolução - RDC n² 275, a implementação dos POPs' deve ser monitorada periodicamente de forma a garantir a finalidade pretendida, sendo adotadas medidas corretivas em casos de desvios destes procedimentos. As ações corretivas devem contemplar o destino do produto, a restauração das condições sanitárias e a reavaliação dos Procedimentos Operacionais Padronizados. Deve-se prever registros periódicos suficientes para documentar a execução e o monitoramento dos Procedimentos Operacionais Padronizados, bem como a adoção de medidas corretivas. Esses registros consistem de anotação em planilhas e ou documentos e devem ser datados, assinados pelo responsável pela execução da operação e mantidos por um período superior ao tempo de vida de prateleira do produto. Deve-se avaliar, regularmente, a efetividade dos POP's implementados pelo estabelecimento e, de acordo com os resultados, deve-se fazer os ajustes necessários. Os Procedimentos Operacionais Padronizados devem ser revistos em caso de modificação que implique em alterações nas operações documentadas (BRASIL, 2002). 
Os POP's foram estabelecidos para os seguintes itens:

\subsection{1) Higienização das instalações, equipamentos, móveis e utensílios:}

\section{Ambiente Geral}

Periodicidade: diariamente (sempre que necessário)

Produto: sabão e/ou detergente e solução clorada.

Procedimento:

- Recolher os resíduos com o auxílio de pás ou similares;

- Lavar com água, sabão e/ou detergente, de acordo com especificação do produto, esfregando bem;

- Enxaguar cuidadosamente, retirando todos os resíduos químicos e físicos;

- Desinfetar;

- Enxaguar (obrigatório na desinfecção química);

- Secar ou puxar a água com rodo;

- Realizar a mesma operação, por partes, em cada setor.

Notas:

1. É proibido varrer a seco os pisos das áreas de manipulação e processamento.

2. Na desinfecção química, deixar o desinfetante em contato mínimo de 15 minutos.

3. Na desinfecção pelo calor, imergir por 15 minutos em água fervente ou no mínimo a $80^{\circ} \mathrm{C}$, dispensando o enxágüe posterior.

4. Na máquina de lavar louça, seguir as temperaturas: lavagem $=55 / 65^{\circ} \mathrm{C}+$ enxágüe $=80 / 90^{\circ} \mathrm{C}$.

5. Na desinfecção química com solução clorada a 200ppm, puxar a água com rodo e deixar secar naturalmente.

6. Realizar a higienização completa, ou seja, com água corrente, fora do horário da produção.

7. Cada área de trabalho deve receber higienização adequada e permanecer limpa, seca e organizada durante todos os períodos. 
8. Higienizar e desinfetar todas as superfícies de trabalho (mesas, bancadas e cubas) antes de iniciar e a cada troca de atividades.

\section{Teto}

Periodicidade: de acordo com a necessidade.

Produto: água e sabão ou detergente neutro.

Procedimento:

A lavagem dessa área é realizada conforme os critérios e orientações do cliente:

- Lavar e enxaguar manualmente ou com máquina própria para este fim;

- Ou solicitar limpeza especializada.

\section{Parede e Vitrôs}

Periodicidade: diária/semanalmente.

Produto: água e detergente neutro.

Solução clorada: $200 \mathrm{ml}$ de água sanitária para 10 litros de água.

Procedimento:

- Desligar e tampar todas as tomadas da área a ser limpa;

- Lavar a superfície com água e solução detergente, de acordo com especificação do produto, com auxílio de esponja;

- Enxaguar com água;

- Finalizar com perfex e solução clorada a 200ppm.

- Deixar secar naturalmente.

Nota:

1. As paredes nas alturas das bancadas de áreas devem ser higienizadas diariamente.

\section{Ralos}

Peridiocidade: diariamente.

Produto: água e detergente.

Solução clorada: $200 \mathrm{ml}$ de água sanitária para 10 litros de água. 
Procedimento:

- Retirar os resíduos sólidos acumulados;

- Lavar com água corrente e detergente, de acordo com especificação do produto;

- Esfregar bem para retirada de toda a gordura ou material sólido existente;

- Enxaguar com água corrente;

- Finalizar com a solução clorada;

- Deixar secar naturalmente.

\section{Portas e Janelas}

Periodicidade: diariamente.

Produto: água e detergente.

Procedimento:

- Lavar o local, inclusive as maçanetas, com água e solução detergente, de acordo com especificação do produto;

- Esfregar com ajuda de esponja;

- Enxaguar com água corrente;

- Finalizar com a solução clorada;

- Deixar secar naturalmente.

\section{Telas}

Periodicidade: mensal e/ou quando necessário.

Produto: água e detergente.

Procedimento:

- Lavar o local com água e solução detergente, de acordo com especificação do produto;

- Esfregar com ajuda de uma escova;

- Enxaguar com água corrente. 


\section{Luminárias, interruptores, tomadas e outros.}

Periodicidade: quinzenalmente ou quando necessário.

Produto: água e detergente.

Procedimento:

- Desligar a corrente elétrica;

- Retirar as lâmpadas para facilitar a limpeza dos suportes;

- Passar pano úmido e detergente neutro, de acordo com as especificações do produto;

- Proceder da mesma maneira com as lâmpadas.

\section{Bancadas e Mesas de apoio}

Periodicidade: diariamente.

Produto: água e detergente neutro.

Solução clorada: $200 \mathrm{ml}$ de água sanitária para 10 litros de água.

Procedimento:

- Lavar com água e detergente, de acordo com especificação do produto;

- Retirar o detergente da bancada usando rodo exclusivo;

- Enxaguar com água;

- Aplicar solução clorada 200ppm por 15 minutos;

- Enxaguar as superfícies que entram em contato direto com os alimentos;

- Deixar secar naturalmente (não usar panos) ou usar rodo exclusivo para este fim (cabo plástico, de metal).

\section{Instalações Sanitárias}

Periodicidade: diariamente.

Produto: água, sabão em pedra ou em pó ou detergente neutro.

Solução clorada: $200 \mathrm{ml}$ de água sanitária para 10 litros de água.

Procedimento:

- Retirar o lixo dos depósitos;

- Lavar piso, paredes, janelas, pias, vasos sanitários e ralos com água e sabão;

- Enxaguar com água corrente; 
- Enxaguar com solução clorada;

- Utilizar o rodo para puxar a água do piso;

- Secar com pano limpo e seco (alvejado);

- Abastecer os toalheiros com papel toalha, as saboneteiras com sabonete líquido.

Notas:

1. Mantê-los sempre limpos e organizados.

2. Prover o local de: sabonete bactericida para as mãos, lixos revestidos de sacos plásticos, papel higiênico e papel toalha.

\section{Higiene de Equipamentos e Utensílios}

Periodicidade: diariamente (sempre que necessário)

Produto: água e produtos específicos para linha industrial

Solução clorada: $200 \mathrm{ml}$ de água sanitária para 10 litros de água.

Procedimento:

- Retirar o excesso de sujidades e/ou recolher os resíduos;

- Umedecer uma esponja em solução detergente;

- Iniciar a lavagem, com água aquecida a $44^{\circ} \mathrm{C}$ (torneira quente);

- Enxaguar em água corrente até remoção total do detergente e demais resíduos;

- Fazer a desinfecção: imergir ou borrifar solução clorada 200ppm, aguardar 15 minutos e enxaguar (água potável ou tratada);

- Deixar secar naturalmente;

- Guardar em local limpo, seco e protegido de respingos, e emborcados (virados para baixo).

Notas:

1. Os utensílios não podem ficar em contato direto com o piso, devendo ser mantidos suspensos em locais apropriados (prateleiras);

- São submetidos a todas as fases de higienização após cada uso; 
- É proibido o uso de escovas, esponjas ou similares de metal, lã e/ou palha de aço, madeira, amianto e materiais rugosos e porosos, para retirada das crostas das panelas ou assadeiras;

\section{Diluição usada para desinfecção}

Solução clorada 200ppm: diluir $100 \mathrm{ml}$ de solução clorada, com 2 a $2,5 \%$ de cloro ativo em 10 litros de água, com freqüência de troca a cada 3 horas.

Álcool a 70\%: diluir $700 \mathrm{ml}$ de álcool comum a $92,8 \%$ em $250 \mathrm{ml}$ de água destilada, com freqüência de troca a cada 24 horas ou álcool a $70 \%$ industrializado, dispensando a troca.

OBS: a cada troca desprezar as sobras de soluções utilizadas.

\section{Exaustor e Coifa}

Periodicidade: semanalmente

Produto: água, detergente neutro, desincrustante e solução clorada 200ppm.

Procedimento:

- Retirar partes móveis;

- Passar pano úmido ou esponja apropriada, com água e detergente e/ou desincrustante, nas partes fixas, para retirar resíduos;

- Enxaguar com água;

- Montar o equipamento;

- Enxaguar com água;

- Enxaguar com solução clorada;

- Deixar secar naturalmente.

\section{Fogão}

Periodicidade: diariamente (a cada troca de turno) / semanalmente.

Produto: água, sabão em pedra ou em pó ou detergente neutro, desincrustante.

Procedimento:

- Deixar esfriar; 
- Retirar os queimadores e ferve-los com água e produto desincrustante, na quantidade estipulada pelo fornecedor;

- Retirar os resíduos e raspar com espátula os mais resistentes;

- Retirar partes móveis e colocar de molho em solução específica por tempo recomendado no produto;

- Lavar com água e detergente, com auxilio de esponja de fibra sintética;

- Enxaguar com água;

- Secar naturalmente.

\section{Forno}

Periodicidade: diariamente (após o uso).

Produto: detergente.

Procedimento:

- Desligar da corrente elétrica (forno elétrico);

- Lavar com água e sabão;

- Retirar os resíduos;

- Colocar as peças removíveis de remolho em solução específica;

- Retirar incrustações com produto específico, segundo orientação do fornecedor, nas manchas de gordura;

- Esfregar com auxilio de esponja de fibra sintética;

- Enxaguar as partes removíveis com água;

- Secar com pano limpo para retirar resíduos e detergente das partes fixas.

\section{Balcão Térmico}

Periodicidade: diariamente após o uso.

Produto: água e detergente.

Procedimento:

- Desligar a corrente elétrica;

- Escorrer toda a água;

- Retirar os resíduos;

- Lavar o local com água e detergente; 
- Limpar com esponja de fibra sintética a superfície interna do equipamento;

- Enxaguar com água;

- Trocar a água diariamente.

\section{Refrigeradores e Freezeres}

Periodicidade: diariamente/semanalmente.

Produto: água e detergente.

Procedimento:

Diariamente:

- Retirar os resíduos e passar pano limpo, umedecido com a solução clorada 200ppm.

\section{Semanalmente:}

- Transferir todos os alimentos para outro equipamento refrigerado, ou no máximo, 30 minutos fora da refrigeração;

- Desligar o motor;

- Lavar internamente e externamente com água, detergente e esponja;

- Enxaguar com água;

- Enxaguar com solução clorada;

- Secar com pano limpo;

- Fechar e ligar o aparelho;

- Após 5 minutos, recolocar os alimentos.

Equipamentos (moedor de carne. Liquidificador, batedeira, multiprocessador, picador de legumes)

Periodicidade: diariamente (após cada tipo de preparo)

Produto: água, álcool a $70 \%$, sabão em pedra ou em pó e detergente neutro.

Solução clorada.

Procedimento:

Partes desmontáveis:

- Retirar as peças cuidadosamente; 
- Lavar peça por peça, com água, sabão e esponja;

- Enxaguar com água;

- Imergir em solução clorada 200ppm por 15 minutos.

\section{Partes Fixas:}

- Retira os resíduos com papel toalha;

- Lavar com água, detergente e esponja, tomando cuidado para não molhar a parte elétrica;

- Retirar o sabão com pano limpo;

- Secar;

- Remontar o equipamento;

- Acondicionar e cobrir com plástico transparente.

\section{Higienização de panos}

Os panos convencionais podem ser utilizados somente para limpeza ambiental, quando necessário, conforme descrito nos POP's específicos. Estes são higienizados diariamente e após o uso.

Os panos de cozinha ou toalhas de mão estão proibidos, pois representam focos de contaminação. Os utensílios são secos naturalmente ou com toalhas descartáveis próprias (perfex), e para as mãos utiliza-se papel toalha branca não reciclado.

\subsection{2) Controle da potabilidade da água:}

A lavagem dos reservatórios de água é realizada a cada 6 meses, por uma empresa terceirizada, contratada pelo cliente.

A análise da potabilidade da água é periódica. Os parâmetros microbiológicos verificados são: Contagem Padrão de Placas (CPP), Coliformes totais e Coliformes fecais. Os limites tolerados estabelecidos pela Portaria $n^{0} 1469$ de 29/12/2000 do Ministério da Saúde são: ausência de Coliformes totais e fecais por $1000 \mathrm{~mL}$ de água e de $500 \mathrm{UFC} / \mathrm{mL}$ de microrganismos aeróbios e/ou facultativos mesófilos (CPP). 


\subsection{3) Higiene e saúde dos manipuladores:}

As etapas, a freqüência e os princípios ativos usados para a lavagem e antisepsia das mãos dos manipuladores devem estão documentados em procedimentos operacionais, assim como as medidas adotadas nos casos em que os manipuladores apresentem lesão nas mãos, sintomas de enfermidade ou suspeita de problema de saúde que possa comprometer a segurança do alimento.

Os exames aos quais os manipuladores de alimentos são submetidos, estão especificados no Manual de Boas Práticas de Fabricação, bem como a periodicidade de sua execução.

O programa de capacitação dos manipuladores em higiene está descrito, sendo determinada a carga horária, o conteúdo programático e a freqüência de sua realização, mantendo-se em arquivo os registros da participação nominal dos funcionários.

\section{Higiene dos manipuladores}

Nota:

1. O cumprimento efetivo dessas regras só é possível através de treinamento e supervisão constante.

\section{Higiene Corporal:}

Os funcionários da UAN devem:

- Tomar banho diariamente;

- Lavar e secar bem os pés;

- lavar a cabeça com freqüência e trazer os cabelos sempre bem escovados;

- Fazer a barba diariamente;

- Apresentar-se com o cabelo aparado;

- Evitar bigodes e costeletas (se apresentá-los estes devem estar bem aparados e limpos);

- Conservar as unhas curtas, limpas e sem esmalte ou base;

- Não utilizar perfumes; 
- Usar desodorante inodoro ou bem suave; não aplicar maquiagem em excesso;

- Manter higiene adequada das mãos;

- Conservar o uniforme limpo, bem passado e trocado diariamente.

\section{Hábitos Pessoais:}

As condutas a seguir não são permitidas pois representam riscos de contaminação alimentar:

- Falar, cantar ou assobiar sobre os alimentos;

- Cuspir;

- Pentear-se;

- Coçar-se ou tocar o corpo;

- Assoar o nariz;

- Espirrar ou tossir sobre os alimentos;

- Circular sem uniformes;

- Enxaguar o suor com as mãos, panos, guardanapos, aventais ou qualquer peça de vestimenta;

- Experimentar comida nas mãos ou com os dedos. Utilizar copo de $50 \mathrm{ml}$ para prova dos alimentos;

- Provar alimentos em talheres e devolvê-los à panela sem prévia higienização;

- Fazer uso de utensílios e/ou equipamentos sujos;

- Mascar gomas, palitos e/ou similares, ou chupar balas;

- Manter lápis, canetas, cigarros ou outros atrás da orelha;

- Manipular dinheiro;

- O uso de agasalhos ou outra peça de roupa sobre o uniforme, se necessário, devem estar por baixo do mesmo;

- Lavar qualquer peça do uniforme na dependência da unidade;

- Roupas e pertences deverão ser guardados em armários individuais e em locais próprios;

- Utilizar acessórios e adereços tais como: anéis, alianças, brinco, colares, relógios, correntes, amuletos, pulseiras e fitinhas. 


\section{Higiene das mãos:}

É importante estimular o hábito de lavar as mãos:

- Ao iniciar o trabalho;

- A cada troca de atividades ou qualquer interrupção;

- Após utilizar sanitários;

- Após tossir, espirrar, assoar o nariz;

- Depois de tocar em dinheiro;

- Antes e após o uso de luvas;

- Todas as vezes que as mãos estiverem sujas;

- Antes de tocar em alimentos já preparados.

\section{Procedimentos para higienização e anti-sepsia das mãos:}

Higiene com sabonete neutro e anti-séptico:

- Umedecer as mãos e antebraços com água;

- Colocar o sabonete líquido, neutro sobre as mãos úmidas;

- Iniciar a massagem das mãos no mínimo 15 segundos, e em seguida o antebraço da mesma forma. Não esquecer das interdigitais;

- Enxaguar bem as mãos e antebraços com água corrente, de preferência quente;

- Aplicar o anti-séptico sobre as mãos, de preferência álcool a 70\%;

- Deixar secar as mãos ao ar naturalmente.

\section{Uso de máscaras}

São utilizadas somente no caso de montagem de marmitas.

As máscaras são:

- descartáveis;

- substituídas por novas a cada trinta minutos no máximo;

- o empregado deve ter consciência da sua utilidade. 


\section{Uso de luvas}

As luvas são utilizadas em caso de ferimentos nas mãos e durante a manipulação de alimentos com contato direto com as mãos.

São utilizadas de maneira correta, principalmente em relação à higiene e desinfecção das mãos antes e após o uso das mesmas.

\section{Luvas Descartáveis}

A adoção de luvas descartáveis plásticas para os seguintes casos:

- Manipulação de alimentos prontos para o consumo e/ou que já sofreram tratamento térmico;

- Manipulação e preparo de alimentos que não são submetidos à tratamento térmico, inclusive folhosos e tubérculos que já foram adequadamente higienizados.

Nota:

1. Em atividades que envolvam temperaturas seu uso é proibido, pois implicam em riscos de acidentes.

2. Ao trocar de tarefa, obrigatoriamente as luvas também devem ser trocadas e as mãos higienizadas.

3. Após os preparos, estas deverão ir para o lixo não sendo reaproveitadas.

4. Uma tarefa extremamente difícil é conscientizar os funcionários sobre a necessidade da higienização freqüente e correta das mãos, geralmente pensam estar com as "mãos limpas", não achando necessário lavá-las periodicamente.

\section{Luvas Térmicas}

São utilizadas como item de segurança, necessitam de dois cuidados especiais:

- adequada higienização;

- cuidar para que não toquem os alimentos em preparação. 


\section{Programa de Treinamento}

Peridiocidade: semestralmente

Conteúdo Programático: Higiene e manipulação de alimentos

Método de Avaliação: Observações diárias

Em Serviços de Alimentação é de extrema importância que se invista em recursos humanos, treinando e desenvolvendo a mão-de-obra.

Os funcionários são sistematicamente orientados sobre as normas de higiene e procedimentos.

\section{Visitantes}

Os visitantes seguem as seguintes exigências:

- utilizar touca ou similares;

- jaleco;

- não utilizar bolsas ou pastas;

- não tocar os alimentos e equipamentos.

\subsection{4) Manejo dos resíduos:}

Lixo

Periodicidade: diariamente/constantemente (2 vezes por turno, ou quando necessário).

Produto: água e detergente.

Procedimento:

- Retirar os sacos e/ou recipientes de lixo em carros próprios;

- Fechar os sacos e colocá-los nos containeres localizados na área externa;

- Lavar os recipientes com água e detergente;

- Enxaguar com água corrente com mangueira;

- Escorrer a água;

- Transportá-los aos seus devidos lugares após higienização;

- Colocar sacos plásticos resistentes em todos os recipientes. 


\subsection{5) Manutenção preventiva e calibração de equipamentos:}

É de responsabilidade do cliente, conforme descrito no contrato de Prestação de serviços.

É realizada quinzenalmente por uma empresa terceirizada. São arquivos os registros que comprovam a calibração dos instrumentos e equipamentos de medição e o comprovante da execução do serviço da calibração.

\section{Manuseio, preservação e armazenamento}

Os equipamentos de medição (termômetros) utilizados são manuseados exclusivamente por pessoal técnico treinado. A preservação e armazenamento dos mesmos devem atender requisitos mínimos estabelecidos pelos fornecedores / fabricantes e não devem ser expostos a ambientes agressivos que causem danos e desgastes excessivos que comprometam a exatidão, adequação e uso.

Eventualmente, ao detectar-se alguma exceção à regra acima, os cuidados quanto o manuseio, preservação e armazenamento deverão estar claramente definidos nas Instruções de Calibração do Equipamento.

\section{Proteção contra ajustes}

A sistemática de proteção às instalações de inspeção, medição e ensaios contra ajustes que possam invalidar as condições de calibração empregadas contemplam:

- Treinamento geral do pessoal com acesso às áreas onde se encontram localizados os equipamentos quanto ao impedimento de se proceder ajustes sem autorização prévia do responsável na área;

- Sempre que possível, em função das características dos equipamentos, adicionalmente utiliza-se das etiquetas com advertências contra ajustes ou lacres físicos nos locais de ajustes. 


\subsection{6) Controle integrado de vetores e pragas urbanas:}

A responsabilidade pela execução do Controle de Pragas é do cliente (contratante) e está estabelecida no Contrato de Prestação de Serviços.

O controle de pragas e roedores é realizado com periodicidade mínima de 6 meses.

\subsection{7) Seleção das matérias-primas, ingredientes e embalagens:}

Todas as matérias primas destinadas ao preparo das refeições são inspecionadas pelo encarregado administrativo, cozinheiro líder ou pela gerente, a fim de garantir a qualidade e o estado dos alimentos.

Os critérios para a seleção e recebimento da matéria-prima, embalagens e ingredientes estão especificados a seguir, de acordo com as observações:

- Data de Validade e de Fabricação;

- Características sensoriais do produto (cor, odor, sabor textura);

- Em produtos de origem animal, verificar o carimbo do SIF;

- Condições de acondicionamento: embalagem limpa e íntegra.

- Adequação da embalagem, de modo que o alimento não mantenha contato direto com papel, papelão ou plástico reciclado.

\section{$\checkmark$ Descarregamento:}

\section{Condições do Transporte}

O veículo é inspecionado pelo funcionário responsável no ato do recebimento, observando os aspectos de higiene, presença de insetos e/ou roedores (através de vestígios de pêlos e fezes), temperatura utilizada no transporte (quando for o caso), e qualquer anormalidade, o fornecedor é notificado pelo responsável técnico da unidade e a mercadoria é devolvida no ato, comunicando imediatamente o Departamento de Suprimentos.

\section{Cuidados no Descarregamento}

- Evitar que as mercadorias caiam no chão, e não arrastar as embalagens;

- Retirar da embalagem mais grotesca como caixas de papelão ou madeira para ser acondicionada em monoblocos fechados; 
- Armazenar imediatamente no estoque seco e/ou no local adequado (refrigeradores, freezeres).

\section{Recebimento de Mercadoria Resfriada}

A temperatura é monitorada, não devendo ultrapassar os limites estabelecidos na tabela 1 (em anexo).

\section{Temperatura de recebimento de gêneros perecíveis}

Nos casos de massas frescas, massas recheadas ou salgados atentar-se as datas de validade e modo de armazenamento, sendo o armazenamento sob refrigeração tem um prazo d validade inferior a 10 dias e no congelamento de 30 dias.

\section{Quantidade e Especificação}

É conferi no momento do recebimento, antes de assinar a Nota Fiscal, se o peso e quantidade recebida estão corretos.

Verificar se a mercadoria especificada na nota é realmente aquela que está sendo entregue e se a mesma consta no seu pedido.

\section{Primeiro Que Vence, Primeiro Que Sai (P.V.P.S)}

Procedimentos:

- Receber os gêneros;

- Conferir os gêneros, quanto: quantidade e/ou peso, características organolépticas, data de fabricação, prazo de validade, nota fiscal e preços;

- Os gêneros recebidos são colocados atrás ou abaixo das já existentes;

- Anotar na ficha de controle do estoque, dados sobre o lote recebido (data da entrada, Nota Fiscal, quantidade e preço);

- Devem ser consumidas em primeiro lugar as com data de entrada mais antiga, prevalecendo-se a data de validade;

- Semanalmente, verificar o prazo de validade dos gêneros armazenados, seguindo a ordem crescente de sua entrada. 


\section{$\checkmark$ Armazenamento de Gêneros Perecíveis:}

São estocadas adequadamente logo após o recebimento.

\section{Carnes:}

- Resfriadas: devem ser mantidas à temperatura de 0 a $10^{\circ} \mathrm{C}$, de acordo com as recomendações dos fabricantes;

- Congeladas: devem ser mantidas à temperatura de $0^{\circ} \mathrm{C}$ ou menos, de acordo com as necessidades dos fabricantes.

Procedimentos:

- Os monoblocos não devem ser colocados diretamente sobre o piso. Utilizar estrados e / ou prateleiras, os quais devem ser retirados periodicamente para limpeza e desinfecção;

- As carnes devem estar identificadas de acordo com o seu tipo, quantidade, data de entrada, fornecedor, número da Nota Fiscal, forma de conservação, data de fabricação e abertura da embalagem;

- Retirar as carnes de sua embalagem original (caixas de papelão, caixas de madeira), acondicionando-as em recipientes adequados e higienizado;

- Gêneros como hambúrgueres não necessitam ser retirados das embalagens originais, colocando as caixas em sacos transparentes.

\section{Frios e Laticínios:}

Procedimentos:

- São armazenados em temperatura de até $10^{\circ} \mathrm{C}$ ou de acordo com o fabricante;

- Os queijos e frios são armazenados empilhados e trançados para uma melhor circulação do ar. As sobras de frios e queijos devem ser embaladas em fita-filme e acondicionadas imediatamente a temperatura de refrigeração;

- logurte e derivados devem ser estocados em suas embalagens originais dentro de sacos transparentes para facilitar sua armazenagem. 
Notas:

1. As portas das câmaras e geladeiras são mantidas sempre fechadas. Abrir o menor número de vezes possível.

2. Gêneros alimentícios não podem ser acondicionados em sacos plásticos (preto, azul, cinza, leitosos, etc), pois os mesmos possuem substâncias tóxicas.

3. Os alimentos são mantidos cobertos com plásticos transparentes.

4. Os alimentos são acondicionados em pequenos lotes, garantindo a circulação de ar frio.

\section{Refrigerador/Freezer:}

Procedimentos:

- Gêneros in natura são colocados nas prateleiras mais baixas;

- Gêneros pré-preparados são colocados nas prateleiras intermediárias;

- Gêneros já trabalhados e prontos são colocados nas prateleiras superiores.

\section{$\checkmark$ Armazenamento de Não Perecíveis:}

\section{Latarias:}

Procedimento:

- Quedas são evitadas, uma vez que podem causar rompimento do verniz e conseqüentemente o contato do alimento com o material da lata, o que poderá comprometer o produto;

- A limpeza da parte externa das latas é realizada antes de serem armazenadas nas prateleiras e periodicamente a fim de mantê-las livres da poeira;

- Depois de abertas, caso o seu conteúdo não seja totalmente utilizado, é acondicionado em recipientes de vidro, inox ou plástico. As informações do rótulo original são transcritas em etiquetas brancas ou similares;

- O empilhamento é feito de forma segura, para evitar quedas e danos. 


\subsection{8) Programa de recolhimento de alimentos:}

O destino de gêneros alimentícios reprovados no controle efetuado segue os procedimentos abaixo descritos:.

- Matérias-primas, ingredientes e embalagens reprovados no controle efetuado na recepção são devolvidos imediatamente para o fornecedor e/ou identificados e armazenados em local separado. 


\section{VII - Conclusão}

Tradicionalmente, as inspeções sanitárias têm sido utilizadas como controle higiênico-sanitário, mas nem sempre podem ser realizadas com freqüência e/ou profundidade suficientes para garantir um nível satisfatório de segurança sanitária do alimento. Mas cabe a cada unidade de alimentação e nutrição (UAN) estarem aplicando técnicas para obter ao máximo resultados positivos.

$\mathrm{Na}$ era da globalização, a qualidade é ponto fundamental para a permanência de empresas no mercado e a tendência observada é a presença de um consumidor cada vez mais exigente e consciente de seus direitos. Por esse motivo, é muito importante que as empresas de alimentação, neste caso, se atentem bastante para seu sistema de controles, determinante do padrão de qualidade.

$\mathrm{Na}$ busca por soluções que satisfaçam seus clientes e consumidores, esta unidade desenvolve produtos e ações educativas, promocionais e sociais, que venham ao encontro das necessidades e anseios de seus clientes. Além disso, buscou-se também a redução dos desperdícios decorrentes da má conservação, armazenamento inadequado, e da manipulação inadequada dos gêneros alimentícios.

Objetivando-se uma maior segurança quanto às condições higiênicosanitárias dos alimentos, foram implantadas as Boas Práticas de Fabricação.Bons resultados já foram conseguidos nesta unidade e outros são possíveis de serem alcançados. A operação busca no dia a dia perceber as possibilidades que existem dentro da unidade.

Para a operacionalização da produção e implantação e implementação de sistemas de qualidade foi fundamental o acompanhamento e a supervisão do nutricionista, profissional capacitado, além do treinamento já realizado e conscientização diária/constante dos funcionários em relação à importância do controle de qualidade.

O planejamento físico adequado tem reflexos positivos, onde observa-se uma maior satisfação dos funcionários, uma diminuição dos custos operacionais, 
podendo estender-se até as motivações psicológicas da clientela que habitualmente freqüenta o restaurante.

Considerando-se todos os itens descritos no Manual de Boas Práticas elaborado, é evidente que esta UAN funciona em boas condições, tendo em vista que é uma unidade nova, bem planejada, com equipamentos novos que atendem adequadamente a produção de refeições coletivas. 


\section{VIII - Referências}

BRASIL. Ministério da Saúde do Brasil. Política Nacional de Alimentação e Nutrição. Disponível em: <http://www.saude.gov.br/sba>. Acesso em: 20 nov. 2003.

BRASIL. Ministério da Saúde. Secretaria de Vigilância Sanitária. Portaria n ${ }^{\circ} 326$, de 30 de julho de 1997. Regulamento técnico sobre as condições higiênico-sanitárias e de boas práticas de fabricação. Diário Oficial da União, de 01/08/97.

BRASIL. Ministério da Saúde. Agência Nacional de Vigilância Sanitária. Resolução RDC $n^{\circ} 275$, de 21 de outubro de 2002. Regulamento Técnico de Procedimentos Operacionais Padronizados aplicados aos Estabelecimentos Produtores/ Industrializadores de Alimentos e a Lista de Verificação das Boas Práticas de Fabricação em Estabelecimentos Produtores/Industrializadores de Alimentos. Diário Oficial da União, de 22/12/00.

CODEX ALIMENTARIUS COMISSION. Codex Guidelines for the Application of the Hazard Analysis Critical Control Point (HACCP) system. Joint FAO/WHO Codex Committee on Food Hygiene. WHO/FNU/FOS/93.3.1993. Annex II

FRANCO, B.D.G. de M.; LANDGRAF, M.; Microbiologia dos Alimentos; São Paulo; Editora Atheneu; 1999.

LIMA, C.R.; Manual Prático de Controle de Qualidade em Supermercados; São Paulo; Livraria Varela, 2001.

LIVEIRA, Y. S.; Fontes de Contaminação de Alimentos. Brasília, 1994.

ORGANIZAÇÃO PANAMERICANA DE SAÚDE/ORGANIZAÇÃO MUNDIAL DE SAÚDE. A saúde no Brasil, 1998. 
RODRIGUES, K..; SALAY, E. Atitudes de granjeiros, atacadistas, varejistas e consumidores em relação à qualidade sanitária do ovo de galinha in natura, Rev. Nutr. [online] set./dez. 2001, vol. 14, n³, p. 185-193. Disponível em: <http://www.scielo.br.> Acesso em 28 nov. 2003.

SEBRAE. Manual de Apoio às Boas Práticas de Fabricação. 2001. (Manual Série Qualidade e Segurança Alimentar).

SILVA Jr, E.A.; Manual de Controle Higiênico Sanitário em Alimentos; $4^{a}$ edição; São Paulo; Editora Varela; 2001.

SOCIEDADE BRASILEIRA DE CIÊNCIA E TENOLOGIA DE ALIMENTOS. Manual de higiene e sanificação para a indústria de alimentos. São Paulo, 1994.

TEIXEIRA, S.M.F.G.; et all.; Administração Aplicada às Unidades de Alimentação e Nutrição; São Paulo; Editora Atheneu; 2000.

VIALTA, A..; MORENO, I.; VALLE, José Leonardo Etore do. Boas Práticas de Fabricação, Higienização e Análise de Perigos e Pontos Críticos de Controle na Indústria de Laticínios, São Paulo, jan./fev. 2002. Disponível em: <http://www.revistalaticinios.com.br.> Acesso em 26 nov. 2003. 
XI - Anexos 
Anexo 1 


\section{Registro de treinamento}

\section{CURSO BÁSICO DE HIGIENE NO PREPARO DE ALIMENTOS}

Público alvo: Funcionários do estabelecimento, manipuladores de alimentos.

Objetivo: Orientar o profissional para o correto procedimento no preparo, recebimento, armazenamento e distribuição dos alimentos, visando a redução das transmissões de doenças por riscos sanitários

\section{Conteúdo:}

- Noções de microbiologia alimentar;

- Noções de doenças transmitidas por alimentos;Cuidados de higiene (pessoal, utensílios, equipamentos, ambiente de trabalho);

- Cuidados nas operações: (recebimento, armazenamento, manipulação, cozimento, distribuição, transporte).

\section{Métodos e Recursos:}

- Projeção de filmes e slides;

- Dinâmica de grupo e estudo de caso;

- Aula expositiva em linguagem adequada ao público alvo.

Carga horária: 4 horas no total

\section{Material:}

- Apostila didática;

- Certificado de participação.

Datas: Oferecido em um dos 2 horários: Das 8:00 às 12:00 horas, ou das 13:00 às 17:00 horas. 
Anexo 2 
Anexo 3 
Anexo 4 
Anexo 5 
Anexo 6 
Anexo 7 
Anexo 8 

